\title{
The Role of Leadership in E-Government Licence Provision at Local Government Level in West Java
}

\author{
Nia Karniawati \\ Universitas Komputer Indonesia \\ Bandung, Indonesia \\ nkarniawati@yahoo.co.id \\ Rahman Mulyawan \\ Padjadjaran University \\ Bandung, Indonesia \\ rahmanmulyawan@yahoo.com
}

\author{
Samugyo Ibnu Redjo \\ Padjadjaran University \\ Bandung, Indonesia \\ samugyo.ir@gmail.com
}

\author{
Utang Suwaryo \\ Padjadjaran University \\ Bandung, Indonesia \\ utang_59@yahoo.com
}

\begin{abstract}
Leadership is a process in order to achieve organizational goals. DPMPTSP West Java is a regional government organization that provides public services of licensing in West Java. DPMPTSP has implemented $e$ government in licensing services by online licensing. The purpose of this research is to know why the leadership is needed in e-government implementation of the licensing service at DPMPTSP West Java. This research was conducted in the licensing service at DPMPTSP West Java using qualitative descriptive methods. The results of the study show that the factor of leadership is the important role in the implementation of $e$ government. Without leader support, the use of e-government will not succeed. DPMPTSP West Java has a visionary leader whose gives a full support to use e-government. The consistency of leaders in the use of information technology has influenced the institution's commitment to the implementation of $e$ government in DPMPTSP West Java.
\end{abstract}

Keywords-leadership, e-governmnet, licensing service

\section{INTRODUCTION}

Leadership is a process in order to achieve organizational goals. Dinas Penanaman Modal dan Perijinan Terpadu Satu Pintu (DPMPTSP) West Java is a regional government organization that provides public services in the field of licensing in West Java. As a government organization, DPMPTSP West Java always tries to improve service to the community by innovating. The use of information technology in government is one example of innovation by the government to improve public services. The use of tecnology information in government is known as egovernment. The implementation of e-government in licensing services in DPMPTSP West Java in this study is online licensing.

The Research about the importance of leadership factors in e-government has been done by Gartina and Thalib (2012), Farid (2015), Sitokdana (2015), and Jayanti (2017) [1]. The different from previous studies, this study examined on all forms of leadership roles. in the use of e-government in West Java DPMPTSP.

\section{METHOD}

The method used is a qualitative research method with a case study approach with descriptive analysis. Source of the data obtained is divided into primary and secondary data. Primary data is the type of data obtained directly from the sources used as research informants. Secondary data is data compiled from information literature, such as textbooks, journals, research results, reports and other documents. Sources of information in this research by assigning competent informants using purposive. Data collection techniques used are: the study of literature, observation and interviews. And data analysis techniques using three components of the analysis, namely data reduction, data presentation and conclusion.

\section{RESULTS}

Leadership support in e-government implementation was disclosed by informants, the Head of DPMPTSP West Java, according to him:

"The point is that a leader must at least know and enjoy the system. If the leader is clumsy (technology stutter) towards the system, then the down will not advance. So I tried to get to know, then understand and enjoy so that the subordinates would feel there was encouragement from the leadership. If the leaders ignore subordinates do not like, I give them freedom, so they feel open. In essence, leaders give encouragement to subordinates to move forward. The choice for each if you want to work casually anywhere can but the results are not developed, this is given a chance to advance, people can see and I encourage them (subordinates) to update and improve"

Based on the results of the interview, the use of information technology in government is very dependent on the leader. As a leader who cares about the development of technology, which ultimately will influence the performance of his subordinates in the use of technology. 
This concern is carried out with the use of technology in daily work. Among them is the use of online facilities, the use of information systems in the execution of daily work. The development of dynamic information technology requires the users to be able to follow the changes that occur. As a leader who always encourages his subordinates to be able to follow developments as an effort to improve capabilities that support the performance of the apparatus.

The same opinion was also expressed by the informant apparatus of the Licensing Department of DPMPTSP West Java, according to him:

"The key to pushing and forcing it is in the leadership, in the first time the introduction is still manual. But now, if there is no barcode the leader will not sign, if the barcode means that it uses the system. Actually, changing that habit has been since 2013, with the change of leadership, the head of the field is now aware of the information technology, the changes are faster".

Based on the results of the interview, the successful use of information technology in the execution of the apparatus's work depends on the leader. The consistency of leaders in the use of information technology will influence the institution's commitment to the e-government implementation. This proves, that the success of the use of information technology in the implementation of the work of the apparatus depends on the leader. The consistency of leaders in the use of information technology has influenced the institution's commitment to the implementation of e-government in DPMPTSP West Java.

\section{DISCUSSION}

Leadership is a process in order to achieve organizational goals. According to Yukl,"Leadership is a process to influence others to understand and agree with what needs to be done and how the task is carried out effectively to facilitate individual and collective efforts to achieve the goals"[2]. He believes that the success of organization goals is highly dependent on the leader with his leadership. A leader must be able to make the members in organization to do their duties to achieve the goals. The role of leaders in organizations is very important. The success of a leader can be measured by the role of the leader in the organization. The role of leaders in organizations is very important. This is in line with what Yukl (2005) stated, according to him the effectiveness of leaders is measured based on the leader's contribution to organization processes become the part of the organization. This explains that a leader must be part of the organization. This is seen from the ability of leaders in running the organization by paying attention to ideas or thoughts that come from members of the organization. Then the ideas are processed into a work plan design in achieving the goals.

So that it can be said that the leader is also a design maker. This is in line with Senge (1996: 338). According to him, in a learning organization, leaders are design builders, servants and teachers [3]. They are responsible for building organizations, where people improve their ability to know complexity, obtain clear vision and improve shared mental models; means they are responsible for learning. Then, Senge explained that a leader has a builder of design, designing the learning process where people throughout the organization can be productive in their relationship with the important problems, and develop their skills by learning.

According of that, the leader has a very importance role in achieving the success of organizational goals. Government organizations basically aim to provide services to the community. To improve these services, the government innovates. One of the innovations made with the use of information technology is known as e-government. The success of using e-government depends on the consistency of government organizations in implementing it, including the support of the leaders of the organization itself.

Furthermore, suggests that the successful of egovernment implementation is depend on information reform and governance reform. The paradigm change in both aspects is very important. the important role in changing these two aspects is the leadership factor. This leadership is related to the abilities and skills of leaders in supporting egovernment implementation. A visionary leader, whose looking ahead will have a positive view of the use of information tecnology in governance. According to Heeks, it concerns: (1) Caring and supporting leaders for institutions in implementing e-government have a very important role. (2) Improving the ability of leaders through leadership training to foster awareness, confidence and commitment of leaders in implementing e-government. (3) Leadership training with a focus on improving the leader's ability to lead, personal skills, planning strategies, the desire to be the best in implementing e-government [4].

Leadership support in e-government implementation will make institutions consistently use information technology in service to the community. Such support is in the form of motivational encouragement from leaders to subordinates, the existence of supporting regulations and of course the availability of adequate infrastructure facilities. For this reason, it is necessary to improve the ability of leaders to foster leadership awareness, confidence and commitment in using information technology. It will encourage his subordinates to have the same commitment. Capacity building is not only done for subordinates but also for leaders. This is to foster the spirit of competition, so that it will do the best.

The role of the Head of DPMPTSP West Java is very important in e-government implementation As a visionary leader, the Head of DPMPTSP West Java has strongly supports the use of information technology in the implementation of licensing services.

Leadership support in the implementation of egovernment has brought DPMPTSP West Java to have received awards related to public service innovation through e-government utilization. The award was obtained in the Public Service Innovation Competition in 2014 and served as a pioneer in implementing PTSP at the provincial level and became a pilot for the implementation of PTSP at the national level. Top 99 Public Service Innovation Award in 2015, innovation in "Makin Terlayani Pegawai On Line" program. Become a corruption prevention pilot project from the Komisi Pemberantasan Korupsi (KPK) with the program " Inovasi Satu Akses Pasti Simpatik Jabar " in 2016. This program is a pilot project to prevent corruption by KPK in 17 provinces in Indonesia. This is a public service innovation carried out by the regional government in the income sector, 
the employee allowance sector and the licensing sector in efforts to prevent corruption.

\section{CONCLUSION}

Based on the explanation above, it can be concluded that the leadership has an important role in the use of egovernment in licensing services at DPMPTSP West Java. DPMPTSP West Java has a visionary leader who provides motivation in the form of support, consistency in the use of e-government in licensing services.

\section{ACKNOWLEDGMENT}

This research was financially supported by The Ministry of Reaseach Technology and Higher Education throught "Beasiswa Pendidikan Pascasarjana Dalam Negeri
(BPPDN)" for the Doctoral scholarship program and funding reaserch by "Penelitian Disertasi Doktor (PDD)" Program in 2017.

\section{REFERENCES}

[1] Gartina dan Thalib, Dhani dan Farid. 2012. Kajian Pengembangan Infrastruktur TIK Mendukung Implementasi E-Government: Studi Kasus

[2] Yukl, Gary. 2005. Kepemimpinan dalam Organisasi. Jakarta: PT.Indeks.

[3] Senge, Peter M. 1996. Disiplin Kelima Seni dan Praktek dari Organisasi Pembelajar. Jakarta: Binarupa Aksara.

[4] Heeks, Richard. 2001. Building E-government for Development: A Framework for National and Donor Action, Paper no. 12. Institute for Development Policy and Management, Machester. 